\title{
Grafting with an Interspecific Hybrid Squash Rootstock Accelerated Fruit Development and Impaired Fruit Quality of Galia Melon
}

\author{
Wenjing Guan', Xin Zhao², and Donald J. Huber \\ Horticultural Sciences Department, University of Florida, Gainesville, \\ FL 32611
}

Additional index words. consumer sensory analysis, female flower, flesh firmness, total soluble solids, vegetative growth, yield

\begin{abstract}
Interspecific hybrid squash (Cucurbita maxima $\times$ Cucurbita moschata) is a wellknown cucurbit rootstock for controlling soilborne diseases and improving abiotic stress tolerance. However, reduced fruit quality has been reported on certain melon (Cucumis melo) cultivars when grafted with squash rootstocks. In this study, a field experiment was designed to explore fruit development and quality attributes of galia melon 'Arava' by grafting with hybrid squash rootstock 'Strong Tosa'. Grafted plants with 'Strong Tosa' showed delayed anthesis of female flowers by $\approx 8-9$ days, but harvest dates were unaffected compared with non- and self-grafted 'Arava' plants. Early and total yields were not significantly different between grafted and nongrafted plants. Grafted plants with 'Strong Tosa' rootstock exhibited accelerated fruit development and greater vegetative growth. During the harvest period, $\approx 27 \%$ of grafted plants with 'Strong Tosa' wilted, which was determined as nonpathogenic. Grafting with 'Strong Tosa' rootstock resulted in reduced fruit total soluble solids (TSS) and consumer rated sensory properties.
\end{abstract}

Vegetable grafting, an effective approach to control soilborne diseases and improve abiotic stress tolerance, has been the subject of increased research in the United States (Kubota et al., 2008). Improved crop yield is often reported in grafted plants of solanaceous and cucurbitaceous crops, particularly with presence of targeted diseases or abiotic stresses (Louws et al., 2010; Schwarz et al., 2010). Grafting may also alter plant growth and development characteristics such as numbers of nodes and lateral branches (Davis and Perkins-Veazie, 2005) and flowering and harvest time (Davis et al., 2008). With the increasing use of grafted vegetable plants, effects of grafting on fruit quality remain an intriguing topic owing to the growing consumer demand for high-quality produce (Rouphael et al., 2010). In addition to TSS and flesh firmness, the most commonly evaluated fruit quality attributes for cucurbits, investigations of fruit quality of grafted plants have been expanded to fruit sensory properties

\footnotetext{
Received for publication 19 June 2015. Accepted for publication 3 Nov. 2015.

This material is based on work that is supported by the National Institute of Food and Agriculture, U.S. Department of Agriculture, under award number LS10-233 and award number 2011-51181-30963. We thank Charles A. Sims for his assistance with the consumer sensory analysis.

${ }^{1}$ Current address: Southwest Purdue Agricultural Center, 4369 North Purdue Road, Vincennes, IN 47591 .

${ }^{2}$ Corresponding author. E-mail: zxin@uff.edu.
}

(Guan et al., 2015; Verzera et al., 2014), volatile profile (Condurso et al., 2012), and health-related compounds (Condurso et al., 2012; Proietti et al., 2008; Zhou et al., 2014). As a result, our understanding of the grafting and rootstock impacts on fruit quality is increasing. The body of literature has shown that in general fruit quality is determined by the scion cultivar and rootstock-scion combination, subject to changes with environmental conditions (Rouphael et al., 2010). Accordingly, rootstock-scion-environment interactions may exhibit a pronounced impact on fruit quality. In the case of specialty melons (Cucumis melo) of diverse genotypes (Guan et al., 2013), grafting different types of melons may be of particular importance in elucidating rootstock-scion-environment interactions.

Interspecific hybrid squash rootstocks (C. maxima $\times$ C. moschata), with characteristic vigorous root systems, tolerance to cold and saline conditions, and resistance to fusarium wilt (caused by Fusarium oxysporum), are among the most common cucurbit rootstocks for production of watermelons (Citrullus lanatus), melons, and cucumbers (Cucumis sativus), whereas their adverse effects on fruit quality have been identified as a major concern (Davis et al., 2008). In our recent studies under different production systems over two production seasons, galia melon 'Arava' (C. melo var. reticulatus) grafted onto interspecific hybrid squash rootstock 'Strong Tosa' (C. maxima $\times$ C. moschata) led to reduced fruit TSS and sensory properties, whereas the honeydew melon 'Honey
Yellow' (C. melo var. inodorus) showed no overt changes in fruit quality in response to grafting with 'Strong Tosa' (Guan et al., 2015). To further elucidate the quality modification of fruit from galia melon 'Arava' grafted with the interspecific hybrid squash rootstock, we conducted follow-up experiments examining the rootstock influence on plant growth and fruit development as related to fruit quality properties.

\section{Materials and Methods}

The field trial was conducted in Spring 2013 at the University of Florida Plant Science Research and Education Unit in Citra, FL. The soil texture is loamy sand. Galia melon 'Arava' with green flesh and yellow netted rind (Johnny's Selected Seeds, Winslow, ME) was grafted onto 'Strong Tosa' interspecific hybrid squash rootstock (Syngenta Seeds Inc., Gilroy, CA), which is known for vigorous root systems and soilborne disease resistances particular to fusarium wilt. Non- and self-grafted 'Arava' plants were included as controls. The scion and rootstock seeds were planted on 10 and 14 Feb., respectively, in the research greenhouse on campus in Gainesville, FL. Seedlings were grafted on 23 Feb. using the one-cotyledon method (Davis et al., 2008). Completely healed grafted plants with three true leaves as well as control plants were transplanted into the field on 19 Mar. The field experiment was arranged in a randomized complete block design with four replications and ten plants per plot. Production practices were followed as described previously (Guan et al., 2014, 2015). Climatic conditions during Mar.-June 2013 and the past 10 years are presented in Table 1.

Anthesis dates of all female flowers were recorded and labeled every day from $16 \mathrm{~d}$ after transplanting (DAT) to 41 DAT. The length of the longest vine was measured on three plants per plot at 36 DAT and 46 DAT. Melons were harvested seven times from 25 May to 10 June at the full-slip stage. The early (fruit from the first two harvests on 25 and 28 May) and total yields were recorded. The harvest dates of fruit developed from the labeled female flowers were recorded. Fruit development durations were calculated on 15-22 fruit per plot. These numbers were averaged for statistical analysis.

Consumer sensory analysis was conducted on 31 May at the University of Florida Sensory Analysis Laboratory in Gainesville, FL. On the day before sensory analysis, 10 fully ripe marketable melons of similar size $(\approx 1.5 \mathrm{~kg}$ per fruit) and without visible defects were harvested from each treatment. Melons were stored at $10{ }^{\circ} \mathrm{C}$ overnight. On the day of the sensory test, melons were cut into halves. Fruit quality measurements including TSS, titratable acidity, flesh firmness, and $\mathrm{pH}$ were measured on one half of each fruit. The other halves were used for consumer sensory analysis. Consumer sensory and quality analyses were performed as described previously (Guan et al., 2015). In 
Table 1. Monthly temperature and precipitation from March to June in 2013 and in the past 10 years at Citra, FL (Source: Florida Automated Weather Network).

\begin{tabular}{|c|c|c|c|c|c|c|c|c|}
\hline & \multicolumn{4}{|c|}{2013 production season } & \multicolumn{4}{|c|}{ Avg of past $10 \mathrm{yrs}^{\mathrm{z}}$} \\
\hline & Avg temp $\left({ }^{\circ} \mathrm{C}\right)$ & Min temp $\left({ }^{\circ} \mathrm{C}\right)$ & Max temp $\left({ }^{\circ} \mathrm{C}\right)$ & Precipitation $(\mathrm{mm})$ & Avg temp $\left({ }^{\circ} \mathrm{C}\right)$ & Min temp $\left({ }^{\circ} \mathrm{C}\right)$ & Max temp $\left({ }^{\circ} \mathrm{C}\right)$ & Precipitation $(\mathrm{mm})$ \\
\hline April & 20.9 & 8.8 & 31.3 & 75.2 & 20.4 & 4.1 & 33.3 & 61.4 \\
\hline
\end{tabular}

${ }^{\mathrm{z}}$ Average of monthly data from 2003 to 2012 .

Table 2. Fruit quality attributes of grafted and nongrafted 'Arava' galia melon.

\begin{tabular}{|c|c|c|c|c|c|c|c|}
\hline \multirow[b]{2}{*}{ Treatment $^{z}$} & \multicolumn{4}{|c|}{ Instrumental measurement } & \multicolumn{3}{|c|}{ Consumer sensory analysis $^{x}$} \\
\hline & $\overline{\mathrm{TSS}^{\mathrm{y}}\left({ }^{\circ} \text { Brix }\right)}$ & Flesh firmness (kgf) & Titratable acidity (\%) & $\overline{\mathrm{pH}}$ & Overall acceptability & Flavor liking & Firmness liking \\
\hline$\overline{\mathrm{NAr}}$ & $7.0 \mathrm{a}^{\mathrm{w}}$ & 1.2 & 0.070 & 6.6 & $5.7 \mathrm{~b}$ & $5.3 \mathrm{~b}$ & $6.1 \mathrm{a}$ \\
\hline $\mathrm{Ar} / \mathrm{Ar}$ & $7.8 \mathrm{a}$ & 1.3 & 0.069 & 6.7 & $6.3 \mathrm{a}$ & $6.2 \mathrm{a}$ & $6.2 \mathrm{a}$ \\
\hline Significance $^{v}$ & $* * *$ & NS & NS & NS & $* * *$ & $* * *$ & $* * *$ \\
\hline
\end{tabular}

${ }^{\text {z }} \mathrm{NAr}=$ nongrafted 'Arava'; $\mathrm{Ar} / \mathrm{Ar}=$ self-grafted 'Arava'; $\mathrm{Ar} / \mathrm{ST}=$ 'Arava' grafted onto 'Strong Tosa'.

${ }^{\mathrm{y}} \mathrm{TSS}=$ total soluble solids.

${ }^{\mathrm{x}}$ Attributes were evaluated on a 9-point hedonic scale: 1 = dislike extremely; $2=$ dislike very much; $3=$ dislike moderately; $4=$ dislike slightly; $5=$ neither like nor dislike; $6=$ like slightly; 7 = like moderately; $8=$ like very much; $9=$ like extremely.

${ }^{\text {w}}$ Means within a column followed by the same letter were not significantly different according to Tukey's honestly significant difference test at $P \leq 0.05$.

${ }_{\mathrm{NS}}, * * *$ Nonsignificant or significant at $P \leq 0.001$, respectively.

the consumer sensory analysis, 106 consumer panelists were asked to rate overall acceptability (appearance, taste, flavor, and texture), flesh firmness liking, and flavor liking using a $1-9$ hedonic scale $(1=$ dislike extremely, $5=$ neither like nor dislike, $9=$ like extremely).

Statistical analysis was performed using the Proc Glimmix procedure of SAS program (version 9.2C for Windows; SAS Institute, Cary, NC). Tukey's honestly significant difference test $(\alpha=0.05)$ was conducted for multiple comparisons of measurements between different treatments.

\section{Results and Discussion}

Similar to our previous observations (Guan et al., 2015), grafting with 'Strong Tosa' resulted in fruit with reduced TSS and lower sensory ratings for overall acceptability, flavor liking, and firmness liking in comparison with non- and self-grafted plants (Table 2). Regardless of the grafting treatment, TSS of 'Arava' was relatively low in the present study. The total precipitation from transplanting to final harvest was $256.5 \mathrm{~mm}$ (Source: Florida Automated Weather Network), which might have contributed to the low TSS. Developed in warm and dry climatic conditions, galia melons demonstrate reduced fruit quality when rainfall occurs during flowering and fruit development (Jett, 2006). The low temperature and frost encountered during the early planting season of this study (Table 1) might have influenced fruit quality. Grafted 'Arava' with 'Strong Tosa' also exhibited weak netting in contrast to fruit from non- and self-grafted plants (data not shown), which might be an indicator of reduced TSS (Nerson, 2008). Interestingly, fruit from self-grafted 'Arava' had higher scores for overall acceptability and flavor liking than nongrafted 'Arava' and grafted 'Arava' with 'Strong Tosa'. No significant differences in fruit flesh (mesocarp)

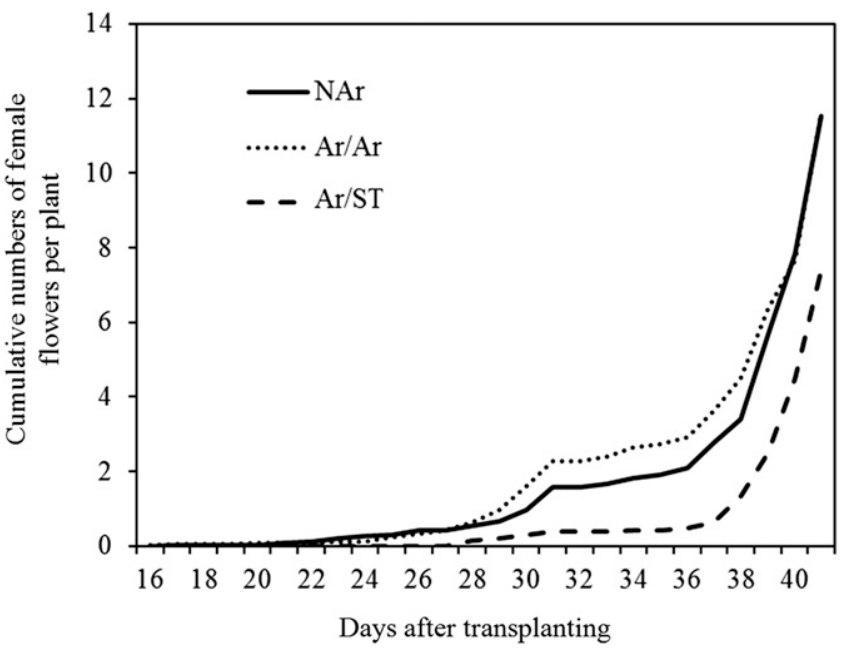

Fig. 1. Cumulative numbers of female flowers per plant in grafted and nongrafted 'Arava' plants from $16 \mathrm{~d}$ after transplanting (DAT) to 41 DAT.

firmness, titratable acidity, and $\mathrm{pH}$ were observed among treatments (Table 2). Because consumer panelists generally lack capability to separate specific fruit quality attributes, lower sensory ratings on firmness liking of grafted melons might be a reflection of reduced sweetness level.

The first female flower of self- and nongrafted 'Arava' plants bloomed around 29 and 30 DAT, respectively, 8 to $9 \mathrm{~d}$ earlier than that of 'Arava' grafted onto 'Strong Tosa' rootstock. At 41 DAT, nonand self-grafted plants had $\approx 12$ blooming female flowers per plant, whereas only 7 were observed on the grafted plants with 'Strong Tosa' rootstock (Fig. 1). Delayed bloom of female flowers was also reported for cucumbers (Satoh, 1996; Yilmaz et al., 2011) and watermelons (Sakata et al., 2007) grafted onto hybrid squash rootstocks. However, in contrast to previous research that reported delay in fruit maturity and harvesting of watermelon and muskmelon grafted onto vigorous rootstocks (Davis et al., 2008), the first harvest date of fruit at full slip from the graft combination was unaffected in this experiment, and the early and total yields did not differ significantly between the grafted and nongrafted plants (Table 3 ). Soteriou et al. (2014) and Kyriacou et al. (2015) found delayed ripening of watermelons from plants grafted with the interspecific squash rootstock and pointed out that the delay in reaching the optimal sweetness may require careful determination of full ripeness before harvest for the grafted watermelon plants. The delayed ripening observed in grafted watermelons might be linked to increased fruit load burdening source-sink relations rather than delayed flowering (Soteriou et al., 2014).

Tracking of the tagged female flowers showed that the duration of fruit development from anthesis to full slip for 'Arava' grafted with 'Strong Tosa' was $\approx 34 \mathrm{~d}$ compared with 38 and 39 d, for non- and self-grafted 'Arava', 
Table 3. Early and total fruit yields of grafted and nongrafted 'Arava' galia melon.

\begin{tabular}{|c|c|c|c|c|c|c|c|c|}
\hline \multirow[b]{2}{*}{ Treatment $^{2}$} & \multicolumn{4}{|c|}{ Early harvest } & \multicolumn{4}{|c|}{ Total harvest } \\
\hline & $\begin{array}{c}\text { Total fruit wt } \\
\text { (kg/plant) }\end{array}$ & $\begin{array}{l}\text { Marketable } \\
\text { fruit wt } \\
\text { (kg/plant) }\end{array}$ & $\begin{array}{l}\text { Total fruit } \\
\text { number } \\
\text { (no./plant) }\end{array}$ & $\begin{array}{c}\text { Marketable fruit } \\
\text { number } \\
\text { (no./plant) }\end{array}$ & $\begin{array}{l}\text { Total fruit wt } \\
\text { (kg/plant) }\end{array}$ & $\begin{array}{l}\text { Marketable } \\
\text { fruit wt } \\
\text { (kg/plant) }\end{array}$ & $\begin{array}{l}\text { Total fruit } \\
\text { number } \\
\text { (no./plant) }\end{array}$ & $\begin{array}{c}\text { Marketable fruit } \\
\text { number } \\
\text { (no./plant) }\end{array}$ \\
\hline $\mathrm{Ar} / \mathrm{ST}$ & 0.36 & 0.28 & 0.5 & 0.3 & 6.5 & 4.2 & 7.2 & 3.9 \\
\hline Significance $^{y}$ & NS & NS & NS & NS & NS & NS & NS & NS \\
\hline
\end{tabular}

${ }^{2} \mathrm{NAr}=$ nongrafted 'Arava'; $\mathrm{Ar} / \mathrm{Ar}$ = self-grafted 'Arava'; $\mathrm{Ar} / \mathrm{ST}=$ 'Arava' grafted onto 'Strong Tosa'.

${ }^{\mathrm{N}_{\mathrm{NS}}}=$ Nonsignificant.

respectively (Table 4). These differences suggest that 'Arava' grafted onto 'Strong Tosa' result in accelerated fruit development. Increased rate of fruit development is often noticed as temperature rises during the production season. Considering that grafted plants delayed fruit set for $8-9 \mathrm{~d}$ in April, the accelerated fruit development might be associated with higher temperature as the season progressed. However, the fluctuation of air temperatures during April to May (Fig. 2) implied that internal plant factors rather than external environmental conditions were more likely to contribute to the accelerated fruit development. Since fruit sugar content is often correlated with duration of fruit development (Burger and Schaffer, 2007), the shorter fruit development period observed in the grafted plants may partially explain the reduced fruit TSS.

Another intriguing observation was that $\approx 27 \%$ of grafted plants with 'Strong Tosa' rootstock had wilted stems and leaves $6 \mathrm{~d}$ after the first harvest. These plants eventually died at the end of the season. Analysis of plant samples by the University of Florida Plant Diagnostic Center (Gainesville, FL) indicated that plant decline was not caused by pathogens. Cell death initiated in the roots and later expanded to the entire rootstock (Fig. 3). During the harvest period, a similar sudden wilt of trellised muskmelon plants grafted onto Cucurbita rootstocks was reported in Israel (Cohen et al., 2007; Davis et al., 2008). Cohen et al. (2007) speculated that the physiological disorder was caused by increased water stress as a result of heavy fruit load on grafted plants. Minuto et al. (2010) also reported sudden collapse and decreased fruit yield of melon plants grafted with hybrid squash rootstocks in Italy. 'Fiola' melon (C. melo var. cantalupensis $)$ grafted onto 'Shintosa' $(C$. maxima $\times C$. moschata) rootstock was the combination most sensitive to sudden collapse. As also noted by Minuto et al. (2010), the vine collapse was more severe with exogenous application of auxins, and when plants were grown under high average temperature $\left(30^{\circ} \mathrm{C}\right)$. In the present study, maximum air temperatures exceeded $30^{\circ} \mathrm{C}$ in the last $30 \mathrm{~d}$ of the growing season, but the average air temperatures were below $27{ }^{\circ} \mathrm{C}$ (Fig. 2). Although it is still unclear about the essential factors resulting in the vine decline of grafted plants during the late production season, the initiation of physiological

Table 4. Duration of fruit development from anthesis to harvest, and length of the longest vine of grafted and nongrafted 'Arava' plants.

\begin{tabular}{lccc}
\hline & $\begin{array}{c}\text { Days from } \\
\text { anthesis to harvest }\end{array}$ & \multicolumn{2}{c}{ Length of the longest vines $(\mathrm{cm})$} \\
\cline { 2 - 4 } Treatment $^{\mathrm{z}}$ & $38 \mathrm{a}^{\mathrm{x}}$ & $72.4 \mathrm{~b}$ & $46 \mathrm{DAT}$ \\
\hline $\mathrm{NAr}$ & $39 \mathrm{a}$ & $71.3 \mathrm{~b}$ & $127.2 \mathrm{~b}$ \\
$\mathrm{Ar} / \mathrm{Ar}$ & $34 \mathrm{~b}$ & $83.0 \mathrm{a}$ & $130.4 \mathrm{~b}$ \\
$\mathrm{Ar} / \mathrm{ST}$ & $* *$ & $*$ & $148.2 \mathrm{a}$ \\
Significance & & $* *$ \\
\hline
\end{tabular}

${ }^{2} \mathrm{NAr}=$ nongrafted 'Arava'; $\mathrm{Ar} / \mathrm{Ar}=$ self-grafted 'Arava'; Ar/ST = 'Arava' grafted onto 'Strong Tosa' . ${ }^{\mathrm{y}} \mathrm{DAT}=$ days after transplanting.

${ }^{x}$ Means within a column followed by the same letter were not significantly different according to Tukey's honestly significant difference test at $P \leq 0.05$.

${ }^{\mathrm{w}} \mathrm{NS},{ }^{*}, * *, * *$ Nonsignificant or significant at $P \leq 0.05,0.01$, or 0.001 , respectively.

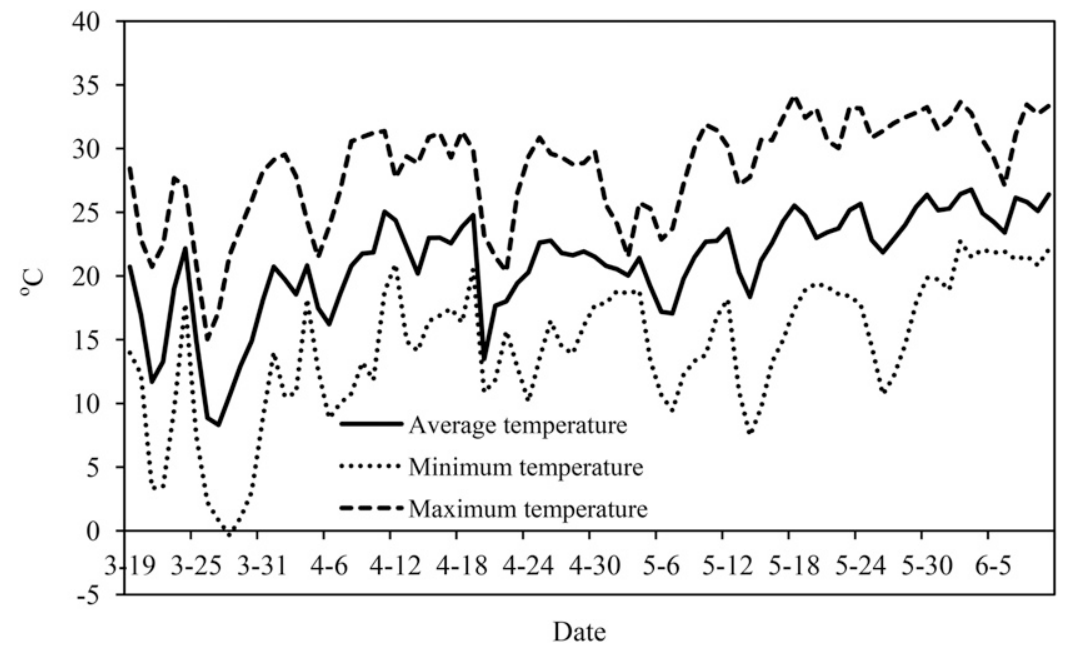

Fig. 2. Air temperature at $60 \mathrm{~cm}$ during the 2013 Spring field experiment at Citra, FL. Source: Florida Automated Weather Network.

collapse of grafted plants might affect fruit development and cause melons to slip early, thus negatively affecting fruit quality attributes. In this study, the fruit used for quality assessment were harvested before plant wilt symptoms were observed in the field.

Although yields were similar among treatments, 'Arava' grafted onto 'Strong Tosa' had significantly longer vines as compared with non- and self-grafted 'Arava' plants at 36 and 46 DAT (Table 4). The enhanced vegetative growth is believed to be associated with vigorous root system that improves water and nutrient uptake (Davis et al., 2008). The plant growth promotion of grafted 'Arava' with 'Strong Tosa' observed in the middle of the production season might have contributed to the increased rate of fruit development.

\section{Conclusions}

Consumer sensory analysis confirmed the reduced eating quality of galia melon 'Arava' as a result of grafting with interspecific hybrid squash rootstock. Further investigation revealed delayed anthesis of female flowers in grafted plants but a lack of significant differences in early and total yields because of grafting. Accelerated fruit development was observed on grafted 'Arava' plants with 'Strong Tosa' rootstock. About $27 \%$ of the grafted plants showed nonpathogenic vine decline during harvest. More indepth studies at physiological and molecular levels are warranted to elucidate the underlying mechanisms for the changes taking place in plant growth and development. The scion-rootstock interactions can be complex given the diverse range of melon types. 


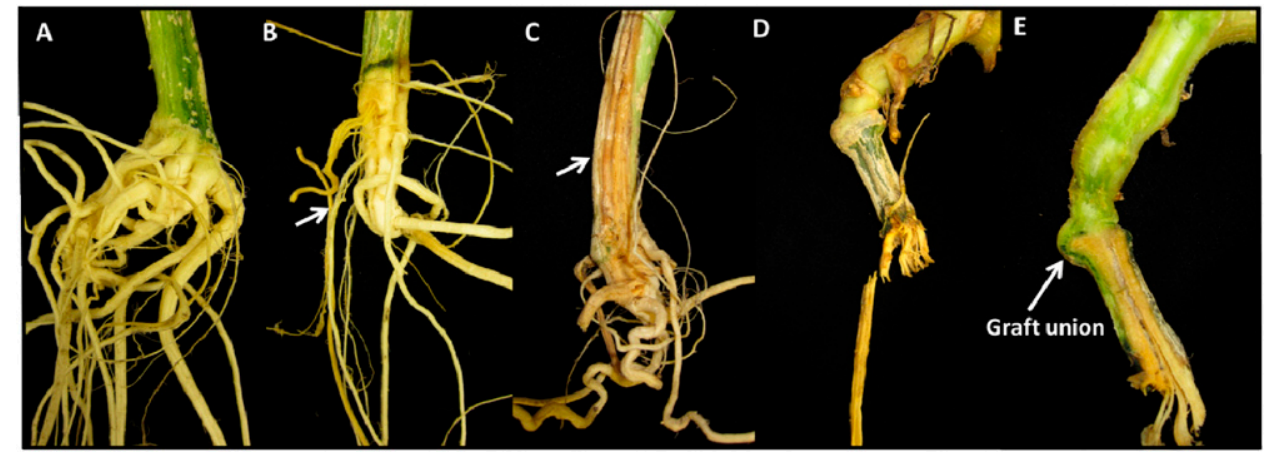

Fig. 3. Roots and stems of 'Arava' grafted onto 'Strong Tosa' rootstock. (A) A healthy root system; (B) Cell death initiated in the roots, as indicated by the arrow; (C) Cell death spread to the stem of rootstock, necrosis of vascular tissue developed as indicated by the arrow; (D) The entire rootstock was dead; (E) Dead rootstock and healthy scion stem separated by the graft union.

Analyzing the performance of various scions grafted onto the interspecific hybrid squash rootstock under varying environmental conditions may help systematically reveal scionrootstock interactions, which could offer insights into identifying factors contributing to the modifications in grafted plants and their influence on fruit development including ripening.

\section{Literature Cited}

Burger, Y. and A.A. Schaffer. 2007. The contribution of sucrose metabolism enzymes to sucrose accumulation in Cucumis melo. J. Amer. Soc. Hort. Sci. 132:704-712.

Cohen, R., Y. Burger, C. Horev, A. Koren, and M. Edelstein. 2007. Introducing grafted cucurbits to modern agriculture: The Israeli experience. Plant Dis. 91:916-923.

Condurso, C., A. Verzera, G. Dima, G. Tripodi, P. Crinò, A. Paratore, and D. Romano. 2012. Effects of different rootstocks on aroma volatile compounds and carotenoid content of melon fruits. Sci. Hort. 148:9-16.

Davis, A.R. and P. Perkins-Veazie. 2005. Rootstock effects on plant vigor and watermelon fruit quality. Cucurbit Genet. Coop. Rpt. 28:39-42.

Davis, A.R., P. Perkins-Veazie, Y. Sakata, S. López-Galarza, J.V. Maroto, S.G. Lee, Y. Huh, Z. Sun, A. Miguel, S.R. King, R. Cohen, and J.M. Lee. 2008. Cucurbit grafting. Crit. Rev. Plant Sci. 27:50-74.

Guan, W., X. Zhao, D.D. Treadwell, M.R. Alligood, D.J. Huber, and N.S. Dufault. 2013. Specialty melon cultivar evaluation under organic and conventional production in Florida. HortTechnology 23:905-912.
Guan, W., X. Zhao, D.W. Dickson, M.L. Mendes, and J. Thies. 2014. Root-knot nematode resistance, yield, and fruit quality of specialty melons grafted onto Cucumis metulifer. HortScience 49:1046-1051.

Guan, W., X. Zhao, D.J. Huber, and C.A. Sims 2015. Instrumental and sensory analyses of quality attributes of grafted specialty melons. J. Sci. Food Agr. 95:2989-2995.

Jett, L.W. 2006. High tunnel melon and watermelon production. Univ. Missouri Ext. M173. 28 Oct. $2015 .<$ http://extension.missouri.edu/p/ M173>.

Kubota, C., M.A. McClure, N. Kokalis-Burelle, M.G. Bausher, and E.N. Rosskopf. 2008. Vegetable grafting: History, use, and current technology status in North America. HortScience 43:1664-1669.

Kyriacou, M.C., G.A. Soteriou, Y. Rouphael, A.S. Siomos, and D. Gerasopoulos. 2015. Configuration of watermelon fruit quality in response to rootstock-mediated harvest maturity and postharvest storage. J. Sci. Food Agr., doi: 10.1002/ jsfa. 7356.

Louws, F.J., C.L. Rivard, and C. Kubota. 2010 Grafting fruiting vegetables to manage soilborne pathogens, foliar pathogens, arthropods and weeds. Sci. Hort. 127:127-146.

Minuto, A., C. Bruzzone, G. Minuto, G. Causarano, G. La Lota, and S. Longombardo. 2010. The physiological sudden collapse of grafted melon as a result of a not appropriate growing procedure. Acta Hort. 883:229-234.

Nerson, H. 2008. Effects of soil type, mineral nutrition and salinity on greenhouse-grown muskmelon in winter. J. Plant Nutr. 15:23812403.

Proietti, S., Y. Rouphael, G. Colla, M. Cardarelli, M. De Agazio, M. Zacchini, E. Rea, S. Moscatello, and A. Battistelli. 2008. Fruit quality of mini-watermelon as affected by grafting and irrigation regimes. J. Sci. Food Agr. 88:1107-1114.

Rouphael, Y., D. Schwarz, A. Krumbein, and G. Colla. 2010. Impact of grafting on product quality of fruit vegetables. Sci. Hort. 127:172-179.

Sakata, Y., T. Ohara, and M. Sugiyama. 2007. The history and present state of the grafting of cucurbitaceous vegetables in Japan. Acta Hort. 731:159-170.

Satoh, S. 1996. Inhibition of flowering of cucumber grafted on rooted squash rootstock. Physiol. Plant. 97:440-444.

Schwarz, D., Y. Rouphael, G. Colla, and J.H. Henk Venema. 2010. Grafting as a tool to improve tolerance of vegetables to abiotic stresses: Thermal stress, water stress and organic pollutants. Sci. Hort. 127:162-171.

Soteriou, G.A., M.C. Kyriacou, A.S. Siomos, and D. Gerasopoulos. 2014. Evolution of watermelon fruit physicochemical and phytochemical composition during ripening as affected by grafting. Food Chem. 165:282-289.

Verzera, A., G. Dima, G. Tripodi, C. Condurso, P. Crinò, D. Romano, A. Mazzaglia, C.M. Lanza, C. Restuccia, and A. Paratore. 2014. Aroma and sensory quality of honeydew melon fruits (Cucumis melo L. subsp. melo var. inodorus $\mathrm{H}$. Jacq.) in relation to different rootstocks. Sci. Hort. 169:118-124.

Yilmaz, S., I. Celik, and S. Zengin. 2011. Combining effects of soil solarization and grafting on plant yield and soil-borne pathogens in cucumber. Intl. J. Plant Prod. 5:95-104.

Zhou, X., Y. Wu, S. Chen, Y. Chen, and W. Zhang. 2014. Using Cucurbita rootstocks to reduce fusarium wilt incidence and increase fruit yield and carotenoid content in oriental melons. HortScience 49:1365-1369. 